http://dx.doi.org/10.4314/jae.v19i2.9

\title{
Comparative Performance Evaluation of the Agricultural Development Programmes of Abia and Enugu States, Nigeria
}

\author{
Umeh, O. J.
}

Department of Agricultural Extension and Rural Sociology

Micheal Okpara University of Agriculture Umudike Umuahia

Abia State. Nigeria

Email: Umehogechi2@yahoo.com

Phone: +2348037420857.

Ekumankama, 0.0.

Department of Agricultural Extension and Rural Sociology

Micheal Okpara University of Agriculture Umudike Umuahia

Abia State. Nigeria

Email: ooekumankama@yahoo.com

\section{Nwachukwu, I.}

Department of Agricultural Extension and Rural Sociology

Micheal Okpara University of Agriculture Umudike Umuahia

Abia State. Nigeria

Email: nwachukwuike@ymail.com

Ekwe, K. C.

Department of Agricultural Extension and Rural Sociology

Micheal Okpara University of Agriculture Umudike Umuahia

Abia State. Nigeria

Email: kcekwe@yahoo.com

\section{Abstract}

This study evaluated the performance of Agricultural Development Programmes (ADPs) of Abia and Enugu states, Nigeria; with particular focus on extension services delivery in the study areas. The specific objectives of the study included to identify and compare the performance of the project in the two states with respect to extension service delivery. Multi-stage sampling technique was used to select 200 respondents made up of 40 extension staff and 60 farmers from each state. Data were obtained from both primary and secondary sources and analyzed using percentages and mean. A hypothesis was postulated and tested in this study using Paired T-test analysis. The results revealed that despite inherent funding problems in ADPs in Nigeria, the two states ADPs were able to carry out some extension activities. These included visits to farmers, conduct of SPATs, and conduct of FNTS/MTs, establishment of MTPs and OFARs among others. Abia ADP had better staff disposition and media coverage than Enugu ADP, A little effort from Abia ADP field staff had a multiplying effect and yielded a higher result as more farm families were reached unlike Enugu ADP that had few field staff and thus achieved very little of their target coverage. Results of the analysis showed that 
out of the 11 extension performance indices measured in the two States ADPS, three showed significant difference at 5\% significance level in the performance of Abia and Enugu states ADPs. They are number of extension agents $\left(6.676^{* *}\right)$, farm visits $\left(5.984^{* *}\right)$ and monthly review meetings (MTRM) $\left(4.588^{* *}\right)$. In view of this result, the study therefore recommended that government should make haste to employ better trained extension staff to enhance extension service delivery in Enugu State. This will speedily revive and sustain grassroots' agricultural production and rural development in the state.

Key words: Evaluation of Extension programmes, Agricultural Development Programmes, Extension Service Delivery.

\section{Introduction}

The most fundamental challenge facing the world today and Nigeria as a country, is food insecurity. It is against this backdrop that the current drive of Nigeria's agricultural policy has been aimed at ensuring sufficient and sustainable export (Udenwa 2003; Nehru, 2009). It was estimated that Nigeria imported about US $\$ 300.00$ million of assorted fruit juice annually when it had a potential to export about US $\$ 4,500.00$ million, if local production was stimulated and encouraged (Obasanjo, 2002). Nigeria has witnessed the birth and death of several notable institutions and organizations fashioned to develop agriculture and reduce poverty. Of all these programs, the Agricultural Development Programme (ADP) is the only one that has survived several administrations in the country, both military and civilian, and have made appreciable impact in agriculture and rural development in the country (Obiechina, 2003).

The ADPs though bedeviled with a lot of constraints like poor funding among others, have shown resilience in the sustenance of agricultural and rural development at the grass root level. It has continued to exist against all odds. How have the ADPs been coping with these numerous challenges? Against this backdrop, it was considered pertinent to do a comparative performance evaluation of two agricultural Development Programmes in the southeastern part of Nigeria, with specific interest in extension services delivery within the period 2006-2008.

\section{Purpose of the study}

Prior to the inception of the ADPs, government launched a number of special programmes which failed to achieve rural development objectives, thereby paving way for a strategy of an integrated approach represented by the Agricultural Development Programme (ADP) system. The system, according to Amalu (1998), is based on the premise that a combination of factors comprising the right technology, effective extension, access to physical input, adequate market and infrastructural facilities were essential to improve farm productivity in other to raise the living standards of the people especially the rural dwellers. 
Information obtained from this work will, therefore, be of immense importance to ADPs and to other similar development institutions. It will offer a resultoriented solution through which performance will be enhanced in the ADP system, and in the other agencies, hence fostering economic growth and development in Nigeria. This study will also guide government's policy makers and ADP management in discovering better systems of allocating fund to the Agricultural Development Programme for provision of extension support services to farmers and other end users of technologies. It will also x-ray the strengths and weaknesses of the state's ADPs under study and serve as guide to strategic planning, highlighting the best ways to achieve the objectives of the ADPs, as extension services agency in Nigeria. Other states can also adopt good strategies that worked for neighbouring states to enhance their own system.

\section{Objectives of the Study}

The study was broadly designed to carry out comparative performance evaluation of the extension delivery system of Abia and Enugu States Agricultural Development Programmes for the period of 2006-2008.

Specifically, the study was designed to identify and compare the performance of the two states ADPs with respect to extension service delivery.

\section{Hypothesis}

In conducting this study the following hypothesis was set and tested:

$\mathrm{HO}$ : There is no significant difference in the performance of Abia and Enugu ADPs in extension services delivery within the period under study.

\section{Methodology}

\section{Area of study}

The study was carried out in the Southeast of Nigeria. The zone is located on latitudes $5^{0} 06^{\prime} \mathrm{N}$ to $6^{0} 34^{\prime} \mathrm{N}$ of the Equator and longitudes $6^{0} 38^{\prime} \mathrm{E}$ and $8^{\circ} 08^{\prime} \mathrm{E}$ of the Greenwich (Prime) Meridian (Microsoft Corporation, 2009). The southeast covers Anambra, Imo, Ebonyi, Abia and Enugu States. The zone is bounded in the east by Rivers and Cross-River states, in the north by Benue state, west by Edo and Delta states and in the south by Akwa lbom state. The zone has tropical climate (hot and warm), all the year round. It has high temperature with annual daily minimum temperature of $24^{\circ} \mathrm{C}$, its relative humidity is lowest during harmattan (Dec, Jan and Feb). Rainy season starts from March to late October and dry season sets in from November to February (Nwogu, 2003; Akoroda, 2005).

The target population of the study is farmers in the study area as well as the extension agents assigned to the selected areas.

\section{Sampling Procedure}


A multi-stage sampling technique was adopted for the selection of respondents for the study. Firstly, two state ADPs namely Abia and Enugu were purposefully selected to represent the study area due to proximity of the two states to each other, (Figure1). The second stage involved purposive selection of all the Chief Extension Officers (CEOs) or Directors of Extension services and Zonal Extension Officers (ZEOs) of the selected state ADPs, This is because these groups of respondents were relatively few in number.

The third stage involved random selection of 6 Block Extension Supervisors (BESs) (2 from each zone). The fourth stage involved random selection of 30 Extension Agents (10 from each zone) from each of the state ADPs under study. The fifth stage also involved random selection of 60 farmers (20 from each zone) from the state ADPs under sturdy.

The sample size for the study therefore was made up of 1 CEO, 3 ZEOs, 6 BESs, 30 EAs and 60 farmers for Abia State ADP and 1 CEO, 3 ZEOs, 6 BESs, 30 EAs and 60 farmers for Enugu State ADP. In all, 2 CEOs, 6 ZEOs, 12 BESs, 60 EAs and 120 farmers constituted the sample size for the study. The total sample size for the study was 200 respondents. 


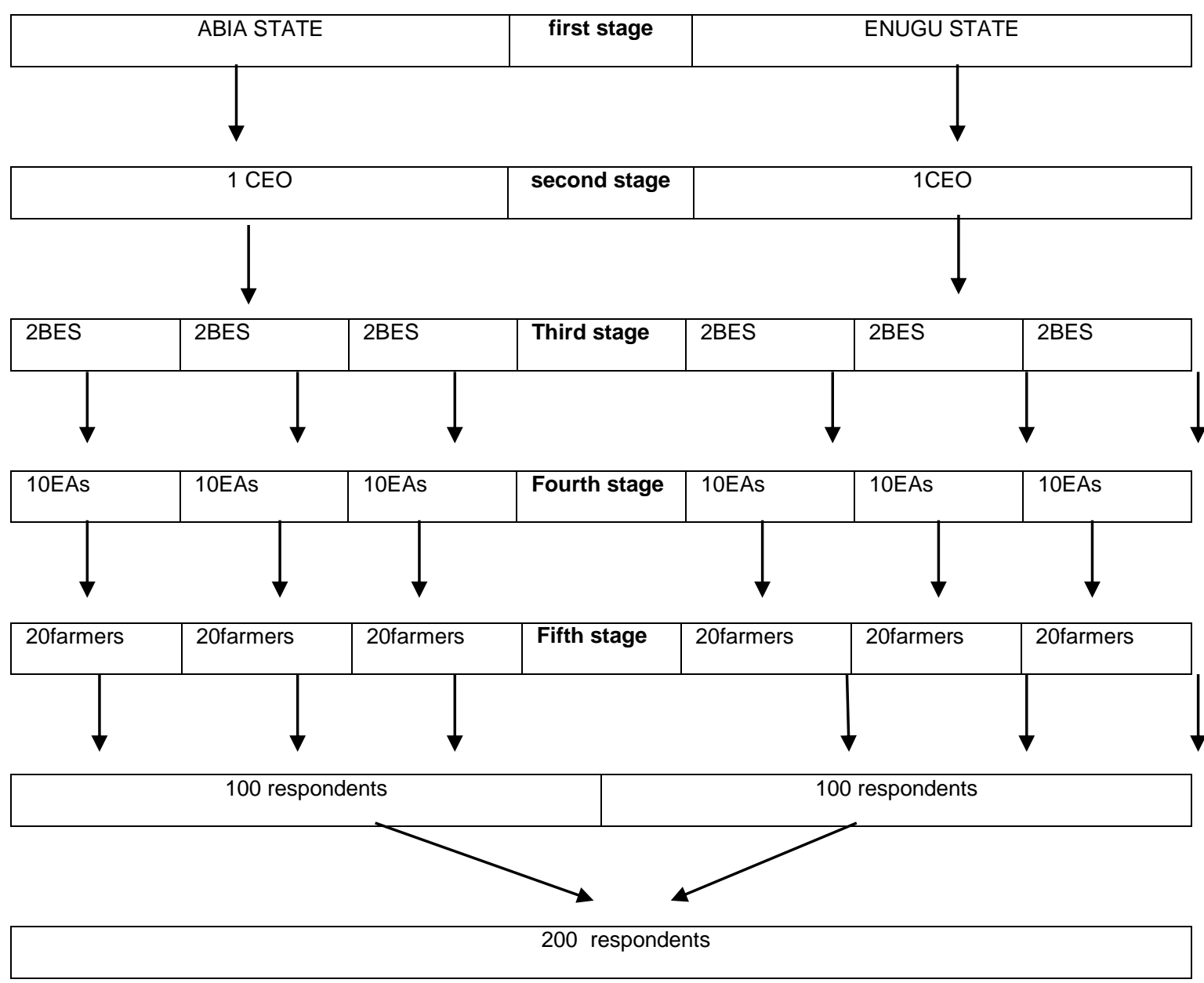

Figure1: diagrammatic representation of the sampling procedure

Data for this study were collected from both primary and secondary sources. Primary data was collected with the aid of two sets of structured pre-tested questionnaires. A set was administered on ADP extension staff, while the other was administered on the farmers. Information gathered was used to corroborate or crosscheck the data from secondary sources.

Secondary data was collected from the Programme Monitoring and Evaluation Unit of the Agricultural Development Programme (ADP) of the states' ADPs under study.

The secondary data collected for the period under review (2006-2008) include extension staff availability, number of farm visits, number of farm trials \& demonstrations, number of SPAT established, number of Subject Matter Specialists (SMS), Ratio of SMS to VEAs, Extension intensity and Extension agent-farmer ratio. 
The Hypothesis was tested at five percent (5\%) confidence level using Paired T-test analysis to determine the significant difference between the performance of Abia and Enugu ADPs in extension services delivery.

\section{Results and Discussion}

Estimated relationships of the performance indices were presented in Table2. Table 3 represents Ratings of Performance Indices within the investigation period (2006-2008) for Abia and Enugu state ADPs.

Results of paired T-test analysis (Table 2) indicate that out of the 11 extension performance indices measured in the two States ADPs, three showed significant difference at $5 \%$ significant level. They are number of extension agents (6.676), farm visits (5.984) and monthly review meetings (4.588). Variables such as block review meetings, fortnightly meetings, SPAT and MTP establishment, staff supervisory visit, WIA activities, media coverage and mobility for extension staff did not have any significant difference in the two state ADPs.

Staff disposition: The result indicated strong significant difference (6.676) in staff availability in Abia and Enugu States ADPs. Earlier, the field survey indicated that Enugu ADP was grossly under staffed having only $19.7 \%$ of its staff requirement while Abia ADP had 68.3\%. For Enugu State to have only 38 members of staff out of its targeted 192 is a strong indication that the extension service delivery in Enugu state is poor. This result buttressed the need for more staff members to be on deck before any meaningful work can be carried out in extension delivery system. Optimum performance in extension services delivery hinges on adequate staff disposition because the EAs go to the circles in different parts of the state meeting framer groups and individual farmers' one on one to disseminate improved production packages from the research institutes as well as giving feedbacks about field problems to the research institutes. This is the main objective of ADP. This result agrees totally with the work of Nwachukwu (2005) that the key to achieve the objectives of extension is the creation of a dynamic link between farmers, professional extension workers and researchers.

Farm visits: The result also shows significant difference (5.984) in the area of farm visit in Abia and Enugu State ADPs. Due to poor staff disposition in Enugu State ADP, farm visits were greatly minimized to only the circles occupied by the available EAs (19.7\%). Therefore not much farm families were visited unlike for Abia ADP that achieved 56.7\% ((State Annual Reports, 2006) of their annual farm visit target because they had higher staff disposition. The finding also agrees with the findings of Ekumankama, Njoku and Tokula (2007) that every EA need to visit the farmers or farmer' groups with relevant messages that are specific to the farm practices in the field at that point in time and this enhances the job performance of EAs. The more the extension workers, the more the area covered. 
Monthly Review Meetings (MTRM): For extension-research contact, the result indicated that there was significant difference $\left(4.588^{* *}\right)$ in the performance of this activity in the two states ADPs. The results in Table 3 earlier revealed that for the period under review, Enugu ADP had no record of its attendance to MTRM, while Abia ADP achieved $56.3 \%$ of its annual target in this activity. MTRM is research - extension synergy where the EAs are educated on improved research findings based on farmer's needs. Any state ADP that does not organise MTRM regularly is obviously giving out obsolete information to their farmers. This result depicts the poor state of extension services delivery in Enugu state because it is constant contact with research institutes that ensures validity of information disseminated to farmers.

Table 2: Difference in the performance of Abia and Enugu State ADPs on extension services delivery

\begin{tabular}{|l|l|l|l|l|l|}
\hline variables & MEAN & $\begin{array}{l}\text { Std. } \\
\text { Deviation }\end{array}$ & $\begin{array}{l}\text { Std. Error } \\
\text { Mean }\end{array}$ & $\mathbf{t}$ & df \\
\hline Staff disposition & 151.33333 & 39.25982 & 22.66667 & $6.676^{\star *}$ & 2 \\
\hline $\begin{array}{l}\text { Farm visits(EAs \& } \\
\text { BEAs) }\end{array}$ & 17618.00000 & 5099.24141 & 2944.04840 & $5.984^{\star *}$ & 2 \\
\hline SPAT Establishment & 2531.33333 & 2054.72756 & 1186.29751 & 2.134 & 2 \\
\hline MTPS Establishment & -484.33333 & 347.69862 & 200.74389 & -2.413 & 2 \\
\hline MTRM & 6.66667 & 2.51661 & 1.45297 & $4.588^{\star *}$ & 2 \\
\hline (FNT) & .00000 & 1.73205 & 1.00000 & .000 & 2 \\
\hline $\begin{array}{l}\text { Block Review } \\
\text { meeting(BRM) }\end{array}$ & .00000 & 1.73205 & 1.00000 & .000 & 2 \\
\hline $\begin{array}{l}\text { Staff Supervisory } \\
\text { Visit(PMU-BES) }\end{array}$ & 527.66667 & 4213.79180 & 2432.83383 & .217 & 2 \\
\hline WIA Activities & 20.00000 & 240.76337 & 139.00480 & .144 & 2 \\
\hline $\begin{array}{l}\text { Media Coverage of } \\
\text { activities }\end{array}$ & 20.00000 & 31.19295 & 18.00926 & 1.111 & 2 \\
\hline Mobility for Ext. staff & 26.00000 & 37.74917 & 21.79449 & 1.193 & 2 \\
\hline
\end{tabular}

${ }^{*} P \leq 0.05$ 
Table 3: Performance indices for Abia and Enugu state ADP (2006-2008)

\begin{tabular}{|l|l|l|l|l|}
\hline Performance Indices & $\begin{array}{l}\text { Mean } \\
\text { target level } \\
\text { (for Abia } \\
\text { State) }\end{array}$ & $\begin{array}{l}\text { Mean } \\
\text { performance } \\
\text { level (\%) (for Abia } \\
\text { State) }\end{array}$ & $\begin{array}{l}\text { Mean target } \\
\text { level (for } \\
\text { Enugu State) }\end{array}$ & $\begin{array}{l}\text { Mean } \\
\text { performance } \\
\text { level (\%) (for } \\
\text { Enugu State) }\end{array}$ \\
\hline No of extension staff & 274 & 68.3 & 192 & 19.7 \\
\hline $\begin{array}{l}\text { Farm visits (EAs \& } \\
\text { BEAs) }\end{array}$ & 46,272 & 56.7 & 10,560 & 54.5 \\
\hline SPAT establishment & 8,480 & 57.3 & 1,485 & 52.7 \\
\hline MTPS establishment & 15 & 64.7 & 825 & 61.4 \\
\hline $\begin{array}{l}\text { Research-ext contact } \\
\text { MTRM }\end{array}$ & 12 & 56.3 & 12 & - \\
\hline Staff training (FNT) & 26 & 92 & 26 & 92 \\
\hline $\begin{array}{l}\text { Block review meeting } \\
\text { (BRM) }\end{array}$ & 26 & 92 & 26 & 92 \\
\hline $\begin{array}{l}\text { Staff supervisory visit } \\
\text { (PMU-BES) }\end{array}$ & 7,596 & 37.8 & 390 & 59 \\
\hline WIA activities & 320 & 60 & 520 & 35 \\
\hline $\begin{array}{l}\text { Media coverage of } \\
\text { activities }\end{array}$ & 82 & 55 & 71 & 23.7 \\
\hline Mobility for ext. staff & 212 & 24.5 & 38 & \\
\hline
\end{tabular}

Sources: Annual REFILS workshop proceedings 2006, 2007 and 2008

\section{Conclusion}

The main thrust of this study was to do a comparative performance evaluation of the agricultural development programme (ADP) in Abia and Enugu States with particular focus on extension services delivery in the study areas within 2006-2008. Analysis of the hypotheses showed that out of the 11 extension performance indices measured in the two State ADPs, three showed significant difference at $5 \%$ level in the performance of Abia and Enugu states ADPs. They are number of extension agents, farm visits and execution of monthly review meetings.

\section{Recommendations}

Analysis of the hypotheses indicated that there is significant difference at $5 \%$ level in the performance of Abia and Enugu state ADPs in the area of staff disposition. The situation where the annual target of staff disposition of Enugu ADP is 192 and they had only 38 staff members shows gross inefficiency. This therefore emphasize the need for the Government of Enugu State to employ more extension staff to salvage extension services in the state. Abia State should also target $100 \%$ staff disposition by employing more hands. 


\section{References}

Akoroda, M. O.(2005). Re-positioning agriculture In South Easth and South South Nigeria Towards National Food security and export. Proceedings Of The 20th Annual Zonal Research Extension Farmer Input Linkage System (REFILS) Workshop S.E Agroecological Zone of Nigeria (Pp. 711). Umudike: NRCRI Umudike.

Amalu, U. C. (1998). Agricultural Research And Extension Delivery System In Sub-Sahara Africa. Calabar: University of Calabar Press.

Ekumankama, O. O., Njoku, C. I., \& Tokula, M. H. (2007). An Assesment of the Job Performance of Extension Agents in Imo State Agricultural Development Programme (ADP). Nigerian Journal of Rural Sociology, vol 3, 10-15.

Microsoft Corporation (2009): Microsoft Encarta Premium Suite 2009 (Software).

Nehru, J. (2009). Encyclopædia Britannica. Encyclopædia Britannica 2009 Student and Home Edition. Chicago: Encyclopædia Britannica.

Nwachukwu, I. (2005). Agricultural Communication: Principles and Practice. Umuahia: lambhouse Publishers.

Nwachukwu, I., \& Onuekwusi, G. (2005). Agricultural Extension And Rural Sociology. Enugu: Snaap Press Ltd.

Nwogu, E. (2003). Abia State Agricultural Development Progrmme Extension Service Report. Proceedings of the 18th Annual zonal Research Extension Farmer Input Linkage Systems (REFILS) workshop, s.e agroecological zone of nigeria. 2nd-5th, december 2003 (pp. 92-103). Umudike: NRCRI.

Obasanjo, O. (2002, July 5). Food Security: the way Forward. Guardian Newspapers , p. 6.

Obiechina, C. O. (2003). The evolving roles of agricultural development programmes (ADPS) in nigerian agricultural development and rural poverty reduction. Proceedings of the 18th annual zonal research extension farmer input linkage system (refils) workshop, S.E.. agroecological zone of nigeria. (pp. 19-44). Umudike: NRCRI Umudike.

State Annual Reports. (2006). Proceedings of The 20th Annual Zonal Research Extension Farmer Input Linkage System (REFILS) workshop S.E. agroecological zone of Nigeria (pp. 15-45). Umudike: NRCRI.

Udenwa, A. (2003). New initiatives in Agricultural Development and Rural Poverty Reduction; A Pragmatic Approach to Good Governance. proceedings of the 18th annual zonal research extension farmer input linkage system (refils) workshop, s.e. agro-ecological zone of Nigeria. (pp. 9-18). Umudike: National Root Crop Research Institute Umudike. 